УДК: 616.12-008.28-073:612.22-073.763.5-053.31

DOI: 10.24061/2413-4260.VIII.3.29.2018.4

\section{В.А Шелевицька}

Державний заклад «Дніпропетровська медична академія МОЗУ»

(м. Дніпро, Україна)

\section{ЕЛЕКТРОННА АУСКУЛЬТАЦІЯ: ПАРАМЕТРИ ФОНОКАРДІОГРАМИ НОВОНАРОДЖЕНИХ ДІТЕЙ РІЗНОГО ГЕСТАЦИИНОГО ВІКУ}

Резюме: Сучасні електронні стетоскопи дозволяють застосовувати аускультацію з одночасною реєстрацією фонокардіограми на записуючий пристрій у новонароджених дітей. Комп 'ютерна обробка отриманої фонокардіограми розщирює можливості діагностики хвороб серия та станів, пов'язаних із особливостями перехідної гемодинаміки новонароджених дітей. Електронна аускультація із подальшою комп'ютерною обробкою фонокардіограми дозволяе визначитись із ї̈ основними параметрами, збільшити кількість та точність їх розрахунку.

Мета. Визначення основних параметрів фонокардіограми та відмінностей між ними у новонароджених дітей різного гестаційного віку.

Матеріали і методи. Обстежено 343 новонароджені дитини з 26 по 41 тиждень гестацї при народженні, у яких пренатально та після народження не було виявлено будь-яких структурних особливостей у сериі та великих судинах. У групі обстежених дітей не визначалися будь-які патологічні зміни при традиційній аускультації. Електронна аускультація виконувалася ичирровим стетоскопом Thinklabs Model ds $32 a+y$ n'яти стандартних точках вислуховування. Запис звуку здійснювався на иифровий диктофон Sопу-ICD-UX71. Доплерехокардіографія виконувалась ультразвуковими сканерами Z.ONE. Ultra фірми ZONARE, MyLab 25 Esaote вiдpaзy після проведення електронної аускультачії. Аналіз отриманих фонокардіограм здійснювався за допомогою розробленої комп'ютерної програми «Неагttone-D». Аналізувалися 9 основних параметрів I і II тону та 9 параметрів проміжків між тонами у п'яти стандартних точках вислуховування.

Результати дослідження. Отримані середні значення показників фонокардіограми 343 новонароджених дітей з 26 по 41 тиждень гестації при народженні та їх відмінності у суміжних за терміном гестації групах. Статистично значимі відмінності у параметрах фонокардіограми новонароджених гестаційним віком 26-28 та 29-31 тижні виявлені у 16 параметрах, 29-31 та 32-34 тижні - у 10 параметрах, 35-36 та 37 - 41 тижні виявлені у 36 параметрах.

Висновки. У параметрах фонокардіограми суміжних за терміном гестації груп недоношених дітей суттєвих відмінностей не виявлено. Виявлені суттєві відмінності між середніми показниками фонокардіограми новонароджених 35-36 тижні гестації та новонародженими 37-41 тижні гестації (загалом по 36 параметрам).

Ключові слова: електронна аускультація; параметри фонокардіограми; новонароджені різного гестаційного віку.

\section{Вступ}

Аускультація, започаткована французьким лікарем Рене Лаенеком, засновником наукової діагностики захворювань пацієнтів («De l'auscultation médiate» 1819), залишається одним із основних методів у діагностиці хвороб серця. Перевагами аускультації є можливість ії застосування та інтерпретації біля ліжка хворого. Однак результати значно залежать від професіоналізму та досвіду лікаря, можливостей стетоскопу, який постійно вдосконалювався 3 часів створення Лаенеком моноаурикулярного стетоскопу у 1816 році. Це і гнучкий біаурикулярний стетоскоп Джорджа Каммана (1835 p), удосконалений фонендоскоп А. Бьянші, Е. Баззі (1894 p), Спрега та Рапапорта (1940 pp).

Значно розширюють можливості аускультації сучасні електронні стетоскопи, у яких одночасно iз вислуховуванням відбувається запис серцевих звуків на пристрій, який може візуалізувати звук, представивши його графічно у вигляді фонокардіограми [1]. Можливість проведення запису у місці постійного перебування пацієнту робить метод електронної аускультації особливо привабливим у обстеженні новонароджених дітей різного гестаційного віку.

Електронна аускультація із наступним комп'ютерним аналізом фонокардіограми може бути застосована для діагностики хвороб серця та станів, пов'язаних із особливостями перехідної гемодинаміки новонароджених дітей $[4,5,6,7]$. Для об'єктивної оцінки фонокардіограми необхідно визначитись із іiї основними параметрами. Опубліковані параметри фонокардіограми доношених новонароджених отримані за допомогою традиційної фонокардіографії (фонокардіографом) характеризують частоту серцевих скорочень, тривалість першого та другого тонів, їх інтенсивність, розщеплення тонів, тривалість серцевого циклу, аналіз наявних систолічних, діастолічних шумів [8,9].

Електронна аускультація із подальшою комп'ютерною обробкою фонокардіограми дозволяє збільшити кількість та точність розрахунку параметрів.

\section{Мета}

Визначення основних параметрів фонокардіограми та відмінностей між ними у новонароджених дітей різного гестаційного віку.

\section{Матеріали і методи дослідження}

Обстежено 343 новонароджені дитини, у яких пренатально та після народження не було виявлено будь-яких структурних особливостей у серці та великих судинах У групі обстежених дітей не визначалися будь-які патологічні зміни при традиційній аускультації. 
За терміном гестації новонароджені розподілилися таким чином: 326 по 28 тиждень - 15 новонароджених ( 8 дівчаток, 7 хлопчиків), мінімальна маса тіла у цій групі становила 470 г, максимальна $-1300,0$, середня маса 930,1;

329 по 31 тиждень - 18 дітей (12 дівчаток, 6 хлопчиків), із мінімальною масою 920,0, максимальною - 1930, середньою масою 1367,8;

332 по 34 тиждень 23 новонароджених (14 дівчаток, 9 хлопчиків) із мінімальною масою 1380,0, максимальною - 2600,0, середньою масою 2009, 1 ;

335 по 36 тиждень - 33 дітей (22 дівчинки, 11 хлопчиків) з мінімальною масою 1900,0, максимальною - 3650,0 середньою масою 2529,4.

Доношені новонароджені 3 терміном гестації 37- 41 тиждень склали групу із 254 дітей (133 хлопчики, 121 дівчинка), із мінімальною масою 2250,0, максимальною - 5100, середньою масою 3421,0

Електронна аускультація виконувалася цифровим стетоскопом Thinklabs Model ds32a+ у режимі максимального підсилення звуку та звуженого сектора вислуховування у п'яти стандартних точках вислуховування. Запис звуку здійснювався на цифровий диктофон Sony-ICD-UX71. Процедура здійснювалася під час сну, або за умови відсутності крику та підвищеної рухливості дитини. Аускультація проводилась у 5 стандартних точках: Тривалість запису у кожній точці становила біля 10-15 секунд, для отримання 20-30 серцевих циклів.

Доплерехокардіографія виконувалась ультразвуковими сканерами Z.ONE.Ultra фірми ZONARE, My Lab 25 Esaote, за уніфікованою методикою, відразу після проведення електронної аускультації.

Аналіз отриманих фонокардіограм здійснювався за допомогою розробленої комп'ютерної програми «Hearttone-D» та включав виділення стабільних фрагментів в точках запису, автоматичне виявлення тонів серця у фрагментах, розрахунок і оцінка параметрів серцевих циклів після ідентифікації серцевих тонів [10]. За допомогою програми були розраховані 96 параметрів для одного серцевого циклу (26 параметрів для першого та другого тонів та 22 параметра для проміжків між першим і другим та другим і першим тоном). Аналізувалися 9 основних параметрів I і II тону та 9 параметрів проміжків між тонами у п'яти стандартних точках вислуховування. Оцінювалися параметри I (s1) та II (s2) тонів: для тонів: ширина тону (width); енергія тону (energy); середні значення всіх максимумів (a_max), мінімумів тону (a_min); максимальне по модулю значення тону та його положення (max_a, max_t); асиметрія положення максимуму відносно ширини (skewnes), кількість перетинів нуля (n zero). Такі ж параметри виділялись i для другого тону - s2 (Рис.1). Аналіз наявності чи відсутності шуму між тонами проводився по чотирьох рівних фрагментах, на які були поділені проміжки між першим і другим тонами - $\mathrm{m} 1$, між другим і першим - m2. Використовувалися такі параметри, як ширина проміжку: width; cyмарна зважена енергія на проміжку energy; кількість нулів n_zero; частота нулів frq_zero; ceредні значення модуля амплітуд mean, mean_1/4, mean_1/4, mean_2/4, mean_3/4, mean 4/4 (Рис.2).

Усї новонароджені у терміні гестації до 28 тижнів були пацієнтами відділення інтенсивної терапії, 11 (73,3\%) новонароджених під час проведення обстеження потребували проведення штучної вентиляції легень (ШВЛ). У 12 (80\%) дітей функціонувала артеріальна протока. У трьох дітей гестаційного віку 28 тижнів протока не функціонувала ( діти були обстежені на 5-ту, 6-ту та 10 добу).

Серед новонароджених 3 терміном гестації при народженні 29-31 тижнів 17 (94,4\%) були пацієнтами відділення інтенсивної терапії, 7 (39\%) під час обстеження потребували проведення ШВЛ, у 13 (72,2 \%) функціонувала артеріальна протока, не функціонувала у п'яти новонароджених: однієї дитини гестаційного віку 31 тиждень (обстежена на 72 годині життя), однієї дитини у терміні гестації 30 тижнів (обстежена на сьому добу життя), двох дітей 3 терміном гестації 29 тижнів (обстежені на першій добі життя), однієї дитини у терміні гестації 30 тижнів (обстежена на сьому добу життя).

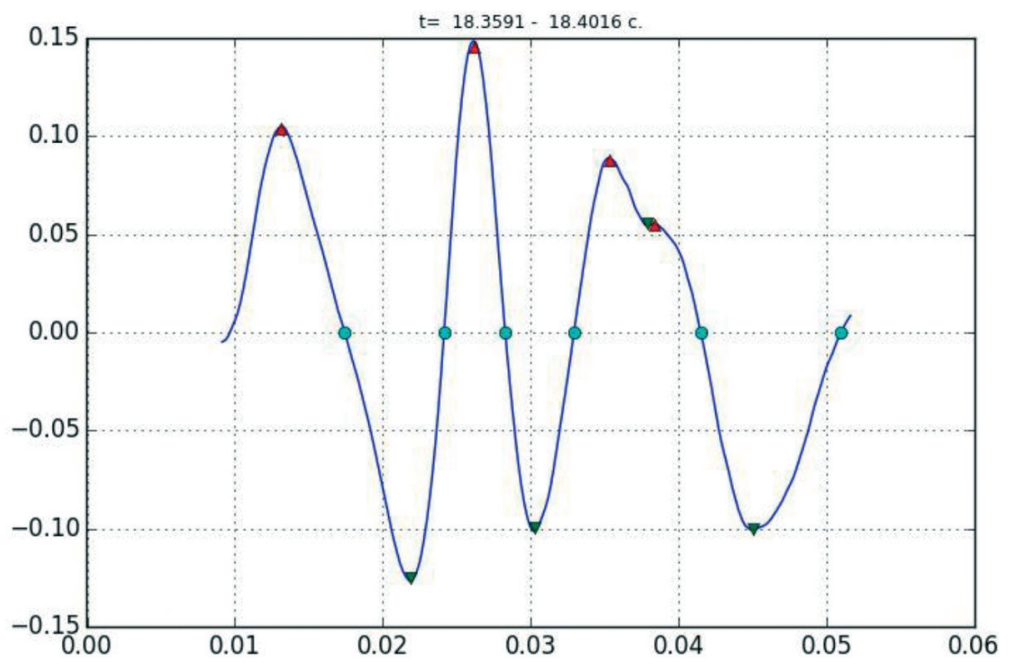

Рис.1 Особливі точки аналізу фонокардіограми тону серця: кружки - нулі, ромби - переломи, трикутник вгору - максимум, трикутник вниз - мінімум 


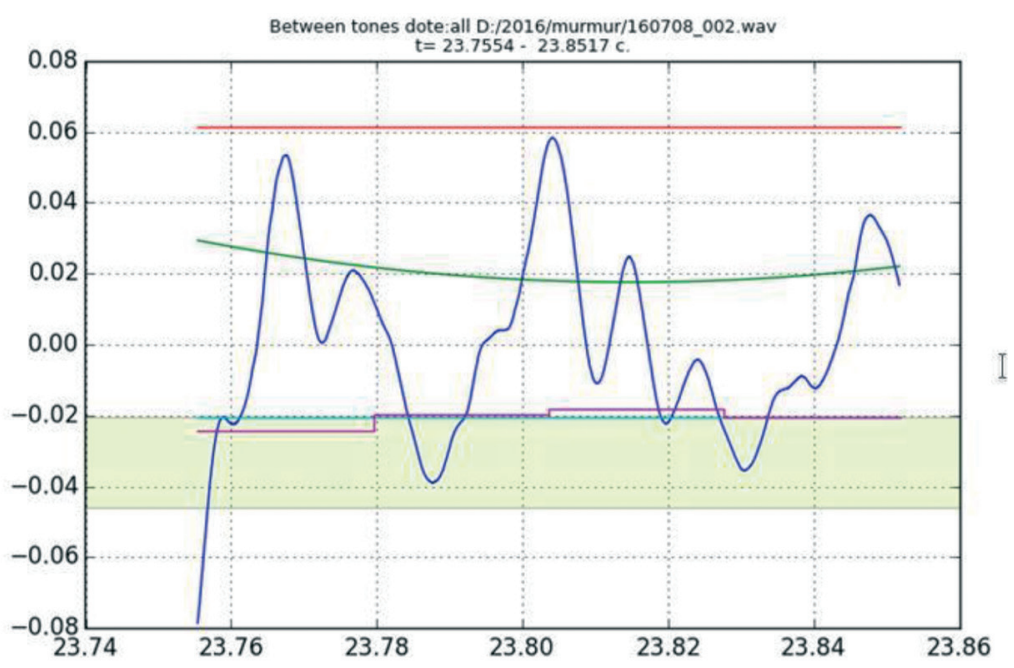

Рис.2 Параметри фонокардіограми проміжку між тонам

Серед новонароджених з терміном гестації при народженні 32-34 тижнів 11(47\%) були пацієнтами відділення інтенсивної терапії, 4(17,4\%) потребували проведення ШВЛ, у $17(73,9 \%)$ функціонувала артеріальна протока. Не функціонувала у $6(26 \%)$ новонароджених: у 4(50\%) дітей із терміном гестації 34 тижні (усі діти обстежені протягом перших трьох діб життя), у 2(33,3\%) новонароджених 3 терміном гестації 33 тижні (обстежені на першій та четвертій добі життя).

Серед новонароджених 3 терміном гестації при народженні 35-36 тижнів 3(9\%) були пацієнтами відділення інтенсивної терапії, 2(6\%) під час обстеження потребували проведення ШВЛ, у 20(60\%) функціонувала артеріальна протока (усі обстежені до четвертої доби життя), не функціонувала у $13(40 \%)$ новонароджених (усі обстежені до четвертої доби життя).

Серед доношених новонароджених 3 терміном гестації при народженні 37-41 тиждень 2 $(0,7 \%)$ новонароджених дітей були пацієнтами відділення інтенсивної терапії, 2 (0,7\%) під час обстеження потребували проведення ШВЛ. Артеріальна протока функціонувала у 98 (38,5\%) новонароджених (у $27(27,5 \%)$ на першу добу життя, $42(42,8 \%)$ на другу добу, 18 (18,3\%) на третю добу, $7(7,1 \%)$ на четверту добу, 2 (2\%) на п'яту добу, 2 (2\%) на шосту добу. У 156 (61,4\%) новонароджених відбулося функціональне закриття протоки (на першу добу у 13 (8,3\%), на другу добу у 69 (44,2\%), на третю добу 56 (35,9\%), на четверту добу $12(7,7 \%)$, на п’яту- $6(3,8 \%)$, В усіх 343 новонароджених функціонувало овальне вікно розміром від 2 до 4,5 мм.

\section{Результати дослідження та їх обговорення}

Отримані параметри фонокардіограми 343 новонароджених дітей з 26 по 41 тиждень гестації. Середні значення показників фонокардіограми новонароджених різного гестаційного віку та їх відмінності у суміжних групах (виділено жирним курсивом) представлені у таблицях. У таблицях в непарних стовпчиках (під номером точки вислуховування) вказано середні значення параметрів фонокардіограми, у парних (під кількістю серцевих циклів) - середньоквадратичне відхилення параметрів. Позначка m праворуч назви параметра означає, що значення рядка помножені на 1000 .

Для порівняння відмінностей між середніми параметрами фонокардіограми в сусідніх за терміном гестації групах новонароджених ( 26-28 та 29-31 тижні, 29-31 та 32-34 тижні, 32-34 та 35-36 тижні, 35-36 тижні та 37-41 тижні) застосовано двовибірковий t-критерій Стьюдента для незалежних вибірок. Статистично значущими вважалися відмінності, для яких критерій Стьюдента перевищував значення 3,0 ( $\mathrm{p}<0.001$ у таблицях виділені жирним курсивом).

Статистично значущі відмінності у параметрах фонокардіограми новонароджених гестаційним віком 26-28 та 29-31 тижні виявлені у 10 параметрах I тону, 3-x параметрах II тону, у 1-му параметру на проміжку між I та II тоном, та 2-х параметрах на проміжку між II та I тоном (загалом у 16 параметрах).

У новонароджених гестаційного віку 29-31 та 32-34 тижні виявлені - у 1-му параметру I тону, 3-х параметрах II тону, та 6-ти параметрах на проміжку між II та I тоном (загалом у 10 параметрах).

У новонароджених гестаційного віку 32-34 та 35-36 тижні виявлені 3-х параметрах II тону, у 4-ох параметрах на проміжку між I та II тоном, та 5-ти параметрах на проміжку між II та I тоном (загалом у 12 параметрах).

У новонароджених гестаційного віку 35-36 та 37 - 41 тиждень виявлені виявлені у 7 параметрах I тону, 16-ти параметрах II тону, у 3-ох параметрах на проміжку між I та II тоном, та 10-ти параметрах на проміжку між II та I тоном (загалом у 36 параметрах). 
Таблиця 1

\section{Середні параметри показників фонокардіограми новонароджених із гестаційним віком при народженні 26-28 тижнів}

\begin{tabular}{|c|c|c|c|c|c|c|}
\hline name & । & $\mathrm{ln}=$ & $\mathrm{n}=$ & 571 & 661 & $\mathrm{ln}=$ \\
\hline \multicolumn{7}{|c|}{$---\mathrm{S} 1-------------------------------------------------------------------------------------------$} \\
\hline I a_max & । & $0.279|0.196|$ & $0.312|0.218|$ & $0.291 \mid 0.2401$ & $0.244|0.173|$ & $0.354|0.174|$ \\
\hline I a min & & $-0.268|0.175|$ & $-0.334|0.230|$ & $-0.282|0.208|$ & $-0.229|0.156|$ & $-0.391|0.189|$ \\
\hline | energy & $\mathrm{m} \mid$ & $1.446|4.133|$ & $2.147 \mid 4.432$ | & $1.276|1.994|$ & $0.885|1.953|$ & $\mathbf{1 . 7 0 0 |} 1.651 \mid$ \\
\hline Imax_a & | & $0.300|0.190|$ & $0.362|0.239|$ & $0.324|0.242|$ & $0.267|0.179|$ & $0.408|0.188|$ \\
\hline In_max & I & $8.422|7.193|$ & $9.934|11.081|$ & $7.03514 .787 \mid$ & $9.530|8.762|$ & 7.64915 .7901 \\
\hline In_min & । & $8.422|7.265|$ & $10.000|11.383|$ & $6.947 \mid 4.8031$ & $9.606|8.674|$ & $7.684|5.756|$ \\
\hline In_zero & । & $10.422|7.554|$ & $11.197|11.058|$ & 8.14014 .9501 & $11.227|9.319|$ & $9.649|6.086|$ \\
\hline Iskewnes & । & $-0.043|0.163|$ & $-0.103|0.170|$ & $-0.069|0.160|$ & $-0.089|0.144|$ & $-0.080|0.155|$ \\
\hline | width & $\mathrm{mc} \mid$ & $72.852|25.721|$ & $75.415|41.333|$ & $66.880|31.389|$ & $70.130|34.887|$ & $74.042|35.067|$ \\
\hline \multicolumn{7}{|c|}{ 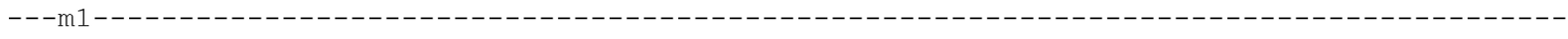 } \\
\hline lenergy (m) & । & $0.223|1.299|$ & $0.237|0.710|$ & $0.148|0.569|$ & $0.051|0.235|$ & $0.087|0.111|$ \\
\hline Ifrq_zero & । & $187.96|91.411|$ & $309.45|1227.2|$ & $224.11|584.67|$ & $300.38|274.38|$ & $184.40|114.54|$ \\
\hline I mean & $\mathrm{m} \mid$ & $13.246|14.921|$ & $18.296|14.541|$ & $14.658|8.138|$ & $8.121|7.468|$ & $14.032|8.705|$ \\
\hline |mean_1/4 & $\mathrm{m} \mid$ & $18.237|36.855|$ & $20.365|16.715|$ & $19.360|14.802|$ & $9.198|9.496|$ & $14.672|10.545|$ \\
\hline |mean_2/4 & $\mathrm{m} \mid$ & $14.068|18.559|$ & $22.315|30.156|$ & $14.275|10.384|$ & $8.136|10.543|$ & $15.704|12.954|$ \\
\hline |mean_3/4 & $\mathrm{m} \mid$ & $10.825|8.538|$ & $16.106|13.133|$ & $12.923|9.997|$ & $7.898|11.499|$ & $12.850|9.139|$ \\
\hline Imean_4/4 & $\mathrm{m} \mid$ & $9.857 \mid 6.6701$ & $14.396|10.260|$ & $12.073|7.401|$ & $7.255|7.470|$ & $12.899|9.213|$ \\
\hline In_zero & । & $27.281|18.324|$ & $54.475|188.40|$ & $53.123|229.58|$ & $42.879|38.915|$ & $30.947|26.286|$ \\
\hline | width & $\mathrm{mcl}$ & $144 \mid$ & 181 & 1481 & $140 \mid$ & 1781 \\
\hline \multicolumn{7}{|c|}{ 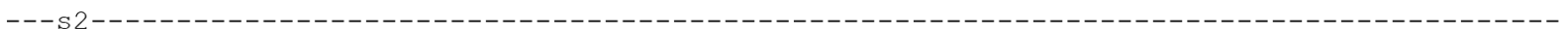 } \\
\hline I a_max & । & $0.234|0.218|$ & $0.186|0.102|$ & 0.19510 .1501 & $0.185|0.181|$ & 0.28510 .2491 \\
\hline a_min & । & $-0.238|0.225|$ & $-0.205|0.115|$ & $-0.237|0.210|$ & $-0.210|0.167|$ & $-0.323|0.266|$ \\
\hline | energy & $\mathrm{m} \mid$ & $0.725|1.262|$ & $0.473|0.595|$ & 0.58410 .7901 & $0.594|1.292|$ & $1.313|2.165|$ \\
\hline Imax_a & । & $0.261 \mid 0.2391$ & $0.221|0.115|$ & $0.254|0.214|$ & $0.226|0.190|$ & $0.336|0.267|$ \\
\hline In_max & । & $5.047|4.804|$ & $4.082|2.083|$ & $3.912|2.357|$ & $6.576|5.480|$ & $5.614|3.407|$ \\
\hline In_min & | & $4.922|4.957|$ & $4.131|2.060|$ & 3.98212 .4391 & $6.606|5.627|$ & $5.719|3.355|$ \\
\hline In_zero & । & 6.46915 .6791 & $5.361|1.984|$ & 5.49112 .9511 & $7.591|5.170|$ & $7.281|4.016|$ \\
\hline I skewnes & । & $-0.031|0.126|$ & $-0.077|0.147|$ & $-0.072|0.131|$ & $-0.060|0.157|$ & $-0.064|0.159|$ \\
\hline I width & $\mathrm{mc} \mid$ & $39.194|19.952|$ & $41.262|17.484|$ & $37.941|13.175|$ & $49.045|27.963|$ & $50.873|24.095|$ \\
\hline \multicolumn{7}{|c|}{ 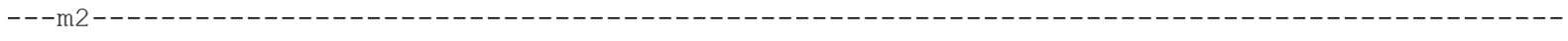 } \\
\hline lenergy $(\mathrm{m})$ & । & $0.194|0.919|$ & $0.105|0.124|$ & $0.086|0.122|$ & $0.024|0.039|$ & $0.082|0.147|$ \\
\hline Ifrq_zero & । & $166.08|70.564|$ & $304.72|952.00|$ & $492.59 \mid 1547.01$ & $295.15|289.59|$ & $172.13|116.41|$ \\
\hline I mean & $\mathrm{m} \mid$ & $13.315|14.660|$ & $15.314|9.084|$ & $13.792|8.714|$ & $7.266|5.246|$ & $13.573|9.684|$ \\
\hline |mean_1/4 & $\mathrm{m} \mid$ & $12.585|8.363|$ & $15.541|9.636|$ & $16.377|11.094|$ & $7.761|5.893|$ & $15.700|13.464|$ \\
\hline |mean_2/4 & $\mathrm{m} \mid$ & $15.172|36.577|$ & $15.929|12.898|$ & 12.49219 .5721 & $6.290|6.376|$ & $13.497|16.789|$ \\
\hline Imean_3/4 & $\mathrm{m} \mid$ & $12.151|10.308|$ & $14.668|11.578|$ & $12.867|12.423|$ & $6.906|6.102|$ & $13.220|10.118|$ \\
\hline |mean_4/4 & $\mathrm{m} \mid$ & $13.351|11.698|$ & $15.120|11.026|$ & $13.43219 .378 \mid$ & $8.107|7.261|$ & $11.871|7.999|$ \\
\hline In_zero & । & $32.188|20.384|$ & $53.689|147.80|$ & $83.000|251.63|$ & $53.909|58.378|$ & $30.702|25.716|$ \\
\hline I width & $\mathrm{mc} \mid$ & 1811 & 1891 & 1741 & $166 \mid$ & 1691 \\
\hline
\end{tabular}

Таблиця 2

Середні параметри показників фонокардіограми новонароджених із гестаційним віком при народженні 29-31 тижнів

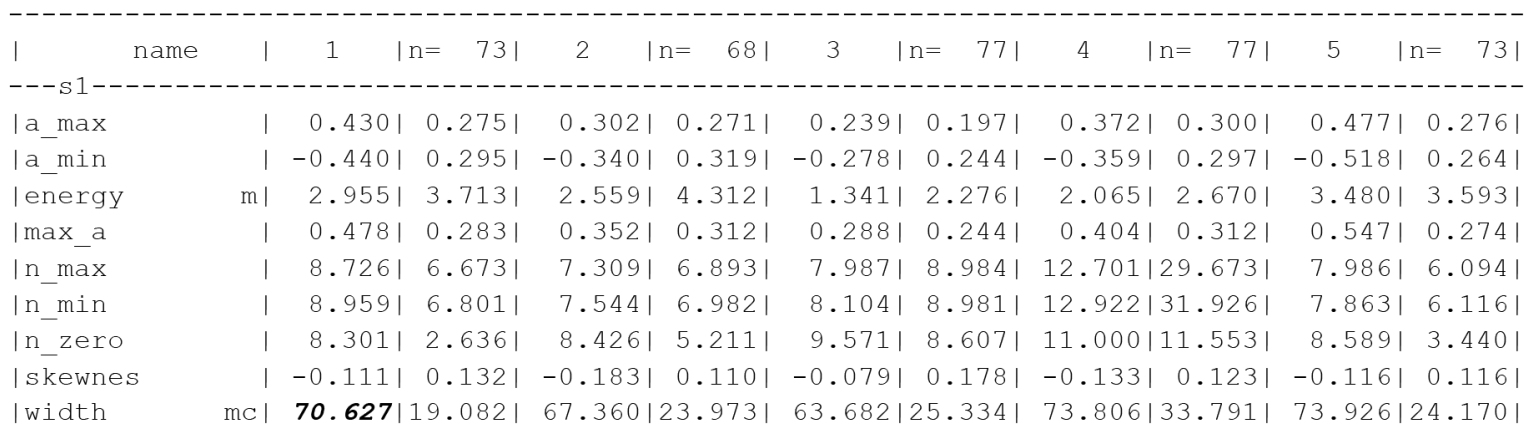




\begin{tabular}{|c|c|c|c|c|c|c|}
\hline | energy (m) & $\mathrm{m} \mid$ & $63.846|78.717|$ & $71.062|68.931|$ & $81.756|158.62|$ & $160.73|983.73|$ & $164.39|384.50|$ \\
\hline | mean & $\mathrm{m} \mid$ & $14.807|9.833|$ & $16.501 \mid 9.8791$ & $14.650|10.134|$ & $11.754|11.950|$ & $20.296|17.022|$ \\
\hline |mean_2/4 & $\mathrm{m} \mid$ & $14.198|11.261|$ & $17.422|13.671|$ & $14.909|12.869|$ & $12.281|19.267|$ & $18.866|15.599|$ \\
\hline mean_3/4 & $\mathrm{m} \mid$ & $14.342|12.524|$ & $15.254|10.301|$ & $13.345|10.484|$ & $9.754|9.594|$ & | $17.613 \mid$ \\
\hline | width & $\mathrm{mc} \mid$ & $134 \mid$ & $132 \mid$ & $138 \mid$ & $136 \mid$ & $132 \mid$ \\
\hline \multicolumn{7}{|c|}{$---\mathrm{S} 2-----------------------------------------------------------------------------------------------$} \\
\hline a_max & | & $0.269|0.231|$ & $0.253|0.205|$ & $0.199|0.181|$ & $0.236|0.212|$ & $0.301|0.235|$ \\
\hline a_min & | & $-0.283|0.252|$ & $-0.235|0.185|$ & $-0.207|0.208|$ & $-0.284|0.265|$ & $-0.341|0.265|$ \\
\hline | energy & $\mathrm{m} \mid$ & 1.00511 .7001 & $0.798|1.048|$ & $0.697|1.301|$ & $1.033|2.117|$ & $1.400|2.159|$ \\
\hline In_zero & | & $6.110 \mid 2.9591$ & $5.368 \mid 2.4791$ & $5.909|2.325|$ & $6.532|3.391|$ & 5.86312 .2101 \\
\hline I skewnes & | & $-0.093|0.135|$ & $-0.044|0.158|$ & $-0.069|0.136|$ & $-0.104|0.136|$ & $\mathbf{- 0 . 0 3 2 | 0 . 1 3 6 |}$ \\
\hline | width & $\mathrm{mc} \mid$ & $39.101|13.295|$ & $\mathbf{3 8 . 4 3 2 | 1 5 . 8 1 4 |}$ & $41.265|18.418|$ & $43.142|19.761|$ & $39.761|15.814|$ \\
\hline & & & & & . & ---- \\
\hline | energy (m) & | & $0.102|0.129|$ & $0.124|0.147|$ & $0.066 \mid 0.0801$ & 0.04410 .06 & 0.18010 .3781 \\
\hline | frq_zero & | & $157.89|85.753|$ & $148.98|72.112|$ & $184.09|182.35|$ & $215.96|110.35|$ & $138.22|54.479|$ \\
\hline | mean & $\mathrm{m} \mid$ & $16.601|10.782|$ & $18.976|12.192|$ & $14.058|8.498|$ & $10.703|8.508|$ & $19.151|12.419|$ \\
\hline | mean_1/4 & $\mathrm{m} \mid$ & $17.734|14.433|$ & $21.635|15.900|$ & $15.541|10.695|$ & $12.909|10.835|$ & $21.667|18.275|$ \\
\hline |mean_2/4 & $\mathrm{m} \mid$ & $14.355|11.438|$ & $16.930|12.890|$ & $12.025|6.659|$ & 9.46219 .6701 & $17.174|14.694|$ \\
\hline |mean_3/4 & $\mathrm{m} \mid$ & $16.673|13.523|$ & $19.462|15.641|$ & $13.821|10.521|$ & $9.979|9.276|$ & $18.320|12.937|$ \\
\hline
\end{tabular}

Таблиця 3

Середні параметри показників фонокардіограми новонароджених із гестаційним віком при народженні 32-34 тижнів

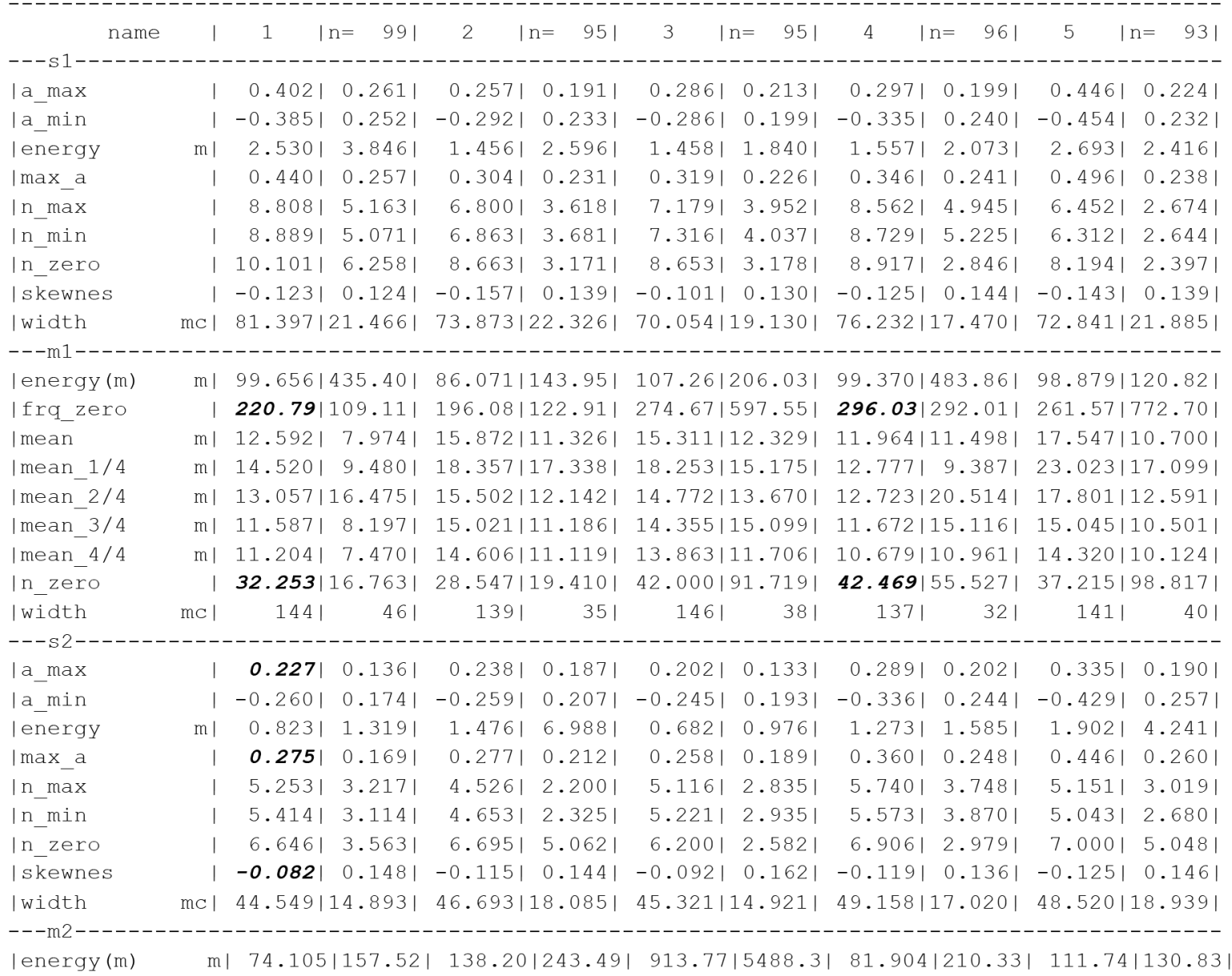




\begin{tabular}{|c|c|c|c|c|c|c|}
\hline Ifrq_zero & I & $198.56|99.457|$ & $240.53|295.19|$ & $261.93|284.41|$ & $271.85|159.60|$ & $\mathbf{2 0 1 . 8 8}|212.25|$ \\
\hline | mean & $\mathrm{m} \mid$ & $13.540|10.573|$ & $16.769|11.938|$ & $18.804|30.466|$ & $11.663|9.765|$ & $17.681|10.652|$ \\
\hline |mean 2/4 & $\mathrm{ml}$ & $11.104|8.890|$ & $15.431|12.650|$ & $17.916|36.625|$ & $11.121|10.966|$ & $17.283|13.322|$ \\
\hline |mean_4/4 & $\mathrm{m} \mid$ & $14.387 \mid$ & 13.0041 & $15.352 \mid$ & $11.608|10.297|$ & $|11.040|$ \\
\hline In_zero & I & $36.263|21.028|$ & $49.779|56.079|$ & $60.758|115.33|$ & $\mathbf{5 4 . 3 4 4 | 4 0 . 5 3 3 |}$ & $38.710|38.463|$ \\
\hline
\end{tabular}

Таблиця 4

\section{Середні параметри показників фонокардіограми новонароджених із гестаційним віком при народженні 35-36 тижнів}

\begin{tabular}{|c|c|c|c|c|c|c|}
\hline & & 1 & 2 & $=1331$ & $|\mathrm{n}=149|$ & | $\mathrm{n}$ \\
\hline & I & $368|0.247|$ & $0.290|0.225|$ & $0.270|0.229|$ & $0.260|0.206|$ & 0.4811 \\
\hline $\min$ & 1 & $-0.357|0.251|$ & $-0.334|0.239|$ & $|-0.299| 0.259 \mid$ & $\mid \begin{array}{lll}-0.249 \mid & 0.206 \mid\end{array}$ & $|-0.480| 0$ \\
\hline nergy & $\mathrm{ml}$ & $2.231|2.767|$ & $2.326|5.519|$ & $|1.558| 2$. & $1.163|2.034|$ & 3.48613 \\
\hline ax_a & . & $0.399|0.270|$ & $0.352|0.246|$ & $|0.313| 0.261 \mid$ & $0.283 \mid 0.2$ & $0.528 \mid 0$ \\
\hline $\max$ & I & $8.206|5.951|$ & $7.014|6.702|$ & $6.617|4.482|$ & $7.705|3.426|$ & 6.3631 \\
\hline $\min$ & । & $8.267 \mid 6.0201$ & $7.281|6.457|$ & $6.654|4.410|$ & $7.765|3.398|$ & 6.253 \\
\hline zero & । & $9.046|3.608|$ & $9.548|11.005|$ & $8.767|5.115|$ & $9.396|4.290|$ & 8.8361 \\
\hline kewnes & । & $-0.114|0.160|$ & $-0.156|0.149|$ & $|-0.113| 0.176 \mid$ & $|-0.156| 0.135 \mid$ & $-0.121 \mid$ \\
\hline idth & 1 & & & $63.2^{7}$ & 75.5 & 75.4 \\
\hline ne & I & $0.118|0.267|$ & $0.625|3.011|$ & 0.32211 & $0.073 \mid 0.2291$ & 0.196 \\
\hline$-z^{z}$ & I & $171.375|76.98|$ & $163.41|71.589|$ & 281 . & $196.83 \mid 102$ & 137 \\
\hline n & $\mathrm{ml}$ & $15.597|12.990|$ & $21.698|41.286|$ & | 17.4 & $11.775 \mid 1$ & 19. \\
\hline an $1 / 4$ & $\mathrm{ml}$ & $19.898|20.280|$ & $24.888|43.910|$ & 20. & $13.591 \mid 15$. & 25 \\
\hline ean_2/4 & $\mathrm{ml}$ & $16.398|17.643|$ & $22.329|48.958|$ & 19. & 11 & 18. \\
\hline $3 / 4$ & $\mathrm{ml}$ & $12.679|10.355|$ & $20.450|46.684|$ & 14.7 & 11.2 & 16 \\
\hline $4 / 4$ & $\mathrm{~m} /$ & 13.4 & 19.1 & 14. & 10. & 18. \\
\hline & I & $24.366|12.241|$ & 24.0 & 38.2 & 25.8 & $21.158 \mid$ \\
\hline vidth & $\mathrm{mcl}$ & $138 \mid$ & 1431 & $147 \mid$ & 128 & $146 \mid$ \\
\hline & & & & & ----- & ------ \\
\hline & । & $0.329|0.189|$ & $0.306|0.211|$ & $0.260|0.205|$ & $0.251 \mid 0$ & $0.414 \mid$ \\
\hline & । & $-0.292 \mid 0$. & $-0.312|0.207|$ & $|-0.296|$ & $-0.314 \mid 0$ & -0 \\
\hline & $\mathrm{ml}$ & $1.061 \mid 1$. & $1.413|2.786|$ & $1.299 \mid 3.1$ & $|0.852| 0$. & $0 \mid 1$ \\
\hline & । & $0.366|0.220|$ & $0.353|0.227|$ & $0.313|0.232|$ & $0.319|0.191|$ & $0.489 \mid 0$. \\
\hline$a x$ & । & $5.779|2.994|$ & $4.815|3.878|$ & $5.203|2.512|$ & $5.268|2.401|$ & $4.856 \mid 1$. \\
\hline n & । & $5.962|3.063|$ & $4.815|3.931|$ & $5.248|2.535|$ & $5.329|2.440|$ & $4.747 \mid 1$. \\
\hline & । & $6.924|3.315|$ & $6.740 \mid 6.0091$ & $7.098|3.394|$ & $7.020|2.407|$ & $6.760 \mid 1$. \\
\hline kewnes & । & $-0.150|0.126|$ & $-0.133|0.125|$ & $\mid \begin{array}{lll}-0.087 \mid & 0.178 \mid\end{array}$ & $|-0.144| 0.147 \mid$ & $-0.117 \mid 0$. \\
\hline vidth & $\mathrm{mcl}$ & $49.960|14.864|$ & $47.272|19.343|$ & $|46.396| 16.715 \mid$ & $|49.042| 13.830 \mid$ & $47.758 \mid 13$. \\
\hline$-m 2--$ & 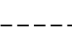 & --- & --------- & -------- & ----------- & ----- \\
\hline & । & $0.109|0.211|$ & $\mathbf{0 . 8 8 8}|4.321|$ & 512 & 0.07310 & 0 \\
\hline 0 & । & 169 & 165. & 175 & 209. & 141 \\
\hline & $\mathrm{ml}$ & & 22.8 & 15. & 10.8 & 20. \\
\hline $1 /$ & $\mathrm{ml}$ & & 25.2 & 17. & 11 & 23. \\
\hline C. & $\mathrm{ml}$ & 13. & 20.1 & 14. & 10 & 19. \\
\hline $3 / 4$ & $\mathrm{ml}$ & 12. & $2|56.336|$ & 14. & 10 & 19. \\
\hline$n-4 / 4$ & $\mathrm{~m} \mid$ & 14.0431 & $23.272|55.022|$ & 17.2 & $11.7 !$ & 22. \\
\hline & । & | 15.194| & $33.973|17.943|$ & $|22.862|$ & $119.882 \mid$ & 28 \\
\hline iidth & $\mathrm{mc|}$ & $187 \mid$ & $198 \mid$ & 196 & $191 \mid$ & $195 \mid$ \\
\hline
\end{tabular}


Таблиця 5

\section{Середні параметри показників фонокардіограми новонароджених із гестаційним віком при народженні 37 та більше тижнів}

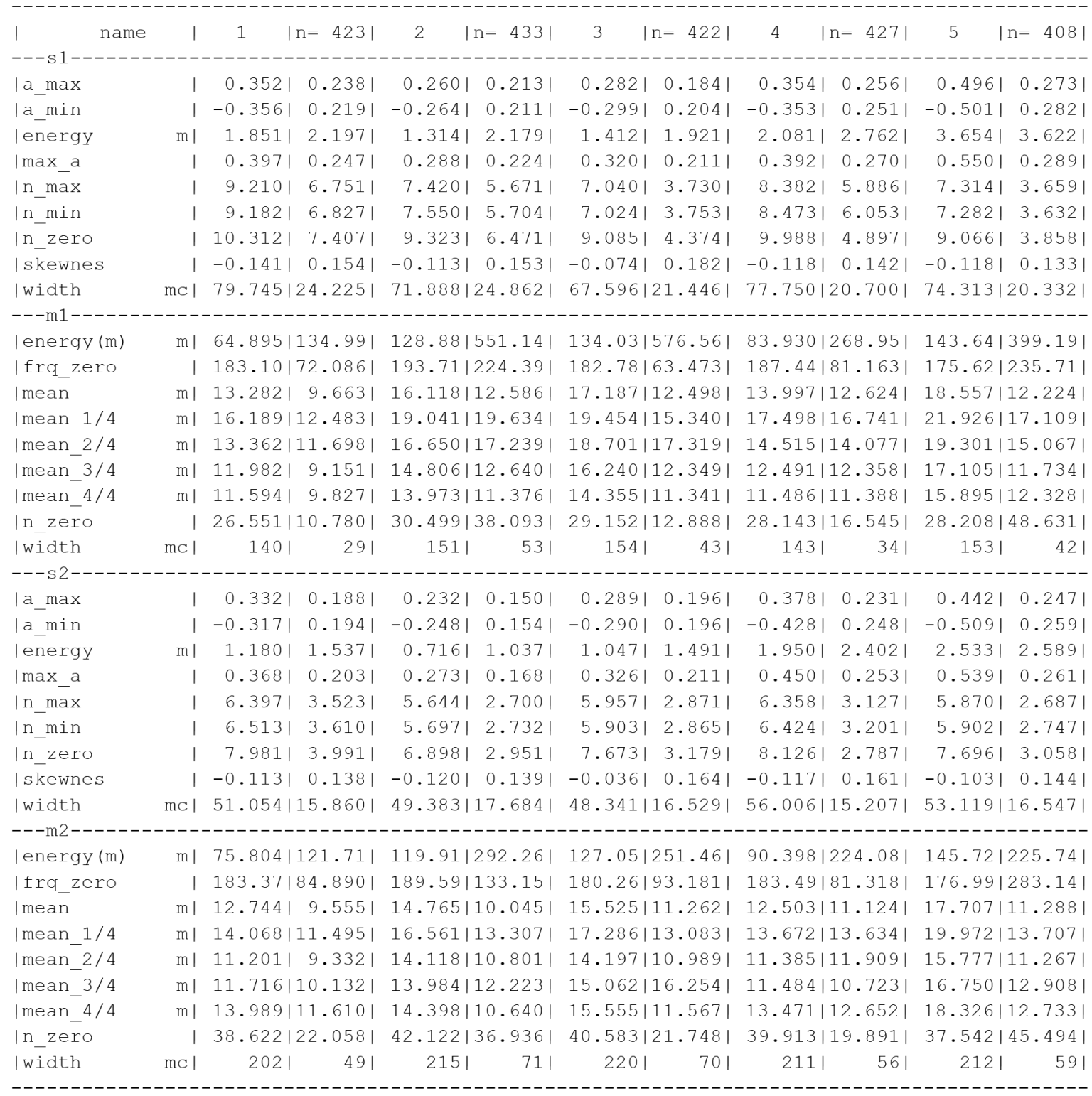

\section{Висновки}

Комп'ютерна обробка фонокардіограми, отриманої шляхом електронної аускультації новонароджених, дозволила визначитися з її параметрами у новонароджених різного гестаційного віку. Аналізувалися 9 основних параметрів I і II тону та 9 параметрів проміжків між тонами у п'яти стандартних точках вислуховування. Отримані середні параметри фонокардіограми для новонароджених 26-28, 29-31, 29-31, 32-34 ,35-36 та 37-41 тижні гестації при народженні.

У параметрах фонокардіограми недоношених дітей, суміжних за терміном гестації груп, суттєвих відмінностей не виявлено. Виявлені суттєві відмінності між середніми показниками фонокардіограми новонароджених 35-36 тижнів гестації та новонароджених 37- 41 тижня гестації (загалом у 36 параметрах одного серцевого циклу у п'яти точках вислуховування). Зважаючи на це, оцінка параметрів фонокардіографії у новонароджених дітей повинна відбуватися відповідно до гестаційного віку при народженні.

\section{Перспективи подальших досліджень}

Враховуючи різноманітність та велику кількість отриманих параметрів, їх застосування для оцінки стану серцевої діяльності новонародженої дитини можливе за умови використання статистичних методів обробки даних. Доцільним $\epsilon$ застосування методів машинного навчання.

\section{Джерело фрінансування}

Дослідження виконано за грантової підтримки Grand Challanges Canada.

\section{Конфлікт інтересів}

Автори не заявляли будь-якого конфлікту інтересів. 


\section{Література}

1. Баранова II, Макарова ОЄ, Мартинюк ТВ, Нікітіна МВ. Дослідження асортименту та етапи товарознавчого аналізу діагностичних медичних приладів: стетоскопів. Управління, економіка та забезпечення якості в фармації, 2017;3(51):61-7. doi: https://doi. org/10.24959/uekj.17.26

2. Yang X, Zeng W. A relative value method for measuring and evaluating neonatal cardiac reserve. Indian J Pediatr. 2010;77(6):661-4. doi: https://doi.org/10.1007/s12098-010-0058-5

3. Balogh ÁT, Kovács F. Application of phonocardiography on preterm infants with patent ductus arteriosus. Biomed Signal Proc and Control. 2011;6(4):337-45. doi: http://doi.org/10.1016/j.bspc.2011.05.009

4.Sung PH, Wang JN, Chen BW, Jang LS, Wang JF. Auditory-inspired heart sound temporal analysis for patent ductus arteriosus. In: 2013 1st International Conference on Orange Technologies (ICOT); 2013 Mar 12-16; Tainan, Taiwan. Taiwan; 2013, p.231-4. doi: https:// doi.org/10.1109/ICOT.2013.6521199

5. Lai LS, Redington AN, Reinisch AJ, Unterberger MJ, Schriefl AJ. Computerized automatic diagnosis of innocent and pathologic murmurs in pediatrics: a pilot study. Congenit heart dis. 2016;11(5):386-95. doi: https://doi.org/10.1111/chd.12328

6. Ghaffari M, Ashourian M, İnce EA, Demirel H. Phonocardiography signal processing for automatic diagnosis of ventricular septal defect in newborns and children. In: 9th International Conference on Computational Intelligence and Communication Networks; 2017 Sep 16-17; Cyprus. Cyprus; 2017, p. 62-66. doi: http://doi.org/10.1109/CICN.2017.8319357

7. Raza A, Faiz SA, Faiz H, Hussain HK, Rizvi SFH. Prevalence of innocent murmur in rural communities of Pakistan. JSZMC. 2018;9(2):1400-1.

8. Arcilla RA, Lind J. Serial Phonocardiography During the Neonatal Period. Zeitschrift fiir Kinderheilkunde. 1965;93(4):354-74.

9. Vukadinović S, WallgrenCG. Evaluation of some electro- and phonocardiographic characteristics of the newborn infant. Biol Neonate. 1971;19(1):170-84. doi: https://doi.org/10.1159/000240411

10. Шелевицький IB, Шелевицька ВА, Семенов БС. Аналіз й класифікація серцевих шумів на основі сплайн-апроксимацій. В: Матеріали Міжн. наук. конф.Інтелектуальні системи прийняття рішень і проблеми обчислювального інтелекту; 2016 Тра 24 та 28 ; Херсон. Херсон: Железный Порт; 2016, с. 233-4

\section{ЭЛЕКТРОННАЯ АУСКУЛЬТАЦИЯ: ПАРАМЕТРЫ ФОНОКАРДИОГРАММЫ НОВОРОЖДЕННЫХ ДЕТЕЙ \\ РАЗЛИЧНОГО ГЕСТАЦИОННОГО ВОЗРАСТА}

\section{В. А. Шелевицкая}

Государственное учреждение

«Днепропетровская медицинская академия МЗ Украины

(г. Днепр, Украина)

Резюме. Современные электронные стетоскопы позволяют применять аускультацию с одновременной регистрацией фонокардиограммы на записывающее устройство у новорожденных детей. Компьютерная обработка полученной фонокардиограммы расширяет возможности диагностики болезней сердца и состояний, связанных с особенностями переходной гемодинамики новорожденных детей. Электронная аускультация с последующей компьютерной обработкой фонокардиограммы позволяет определиться с ее основными параметрами, увеличить количество и точность их расчета.

Цель. Определение основных параметров фонокардиограммы и различий между ними у новорожденных детей различного гестационного возраста.

Материалы и методы. Обследованы 343 новорожденных ребенка с 26 по 41 неделю гестации при рождении, у которых пренатально и после рождения не было выявлено каких-либо структурных особенностей в сердце и крупных сосудах. В группе обследованных детей не определялись какие-либо патологические изменения при традиционной аускультации. Электронная аускультация выполнялась цифровым стетоскопом Thinklabs Model DS32 + в пяти стандартных точках выслушивания. Запись звука производилась на цифровой диктофон SonyICD-UX71. Доплерехокардиография выполнялась ультразвуковым сканером Z.ONE.Ultra фирмы ZONARE, My Lab 25 Esaote сразу после проведения электронной аускультации. Анализ полученных фонокардиограмм осуществлялся с помощью разработанной компьютерной программы «Hearttone-D». Анализировались 9 основных параметров I и II тона и 9 параметров промежутков между тонами в пяти стандартных точках выслушивания.

Результаты исследования. Получены средние значения показателей фонокардиограммы 343 новорожденных детей с 26 по 41 неделю гестации

\section{ELECTRONIC AUSCULTATION: PARAMETERS OF THE PHONOCARDIOGRAPHY OF NEWBORNS OF DIFFERENT GESTATIONAL AGE}

\author{
V.A. Shelevytska \\ Dnipropetrovsk state medical academy \\ of Ministry of health \\ of Ukraine \\ (Dnipro, Ukraine)
}

Summary. Auscultation remains one of the main methods in heart disease diagnostics. An electronic auscultation with the subsequent computer analysis of the received phonocardiogram can be used to diagnose conditions associated with the peculiarities of transient hemodynamics of newborn, birth defects and other heart diseases in newborns. An electronic auscultation with further computer processing of the phonocardiograms can determine their main parameters, optimize their quantity and increase the accuracy of the computer analysis.

The aims. Determination of the basic parameters of the phonocardiogram and the differences between them in newborns of different gestational age.

Materials and methods of research. 343 newborn babies of gestational age 26 to 41 weeks were examined. In the group of examined children, no structural defects of the heart and large vessels were found prenatal or after birth as well as no pathological changes were detected using traditional auscultation. The following study using electronic auscultation was performed by the digital stethoscope Thinklabs Model ds32a + at five standard listening points. The sound recording was performed on the Sony-ICD-UX71 digital voice recorder. Doppler sonography was performed by ultrasound Z.ONE.Ultra ZONARE, My Lab 25 Esaote ultrasound scanners immediately after an electronic auscultation. The analysis of received phonocardiograms was carried out with the help of the developed computer program "Hearttone-D". 9 basic parameters of I and II tone and 9 parameters of intervals between tones at five standard listening points were analyzed.

Results of the research. The mean parameters of the phonocardiograms of 343 newborns of gestation age 26 to 41 weeks as well as differences in parameters between the adjacent gestational periods were obtained.

Statistically significant differences in the parameters of the neonatal phonocardiography in gestational age 26-28 and 29-31 weeks were detected in 16 parameters, 
при рождении и их различия в смежных по сроку гестации группах. Статистически значимые различия в параметрах фонокардиограммы новорожденных гестационным возрастом 26-28 и 29-31 недели выявлены по 16 параметрам, 29-31 и 32-34 недели по 10 параметрам, 35-36 и 37 - 41 неделя обнаружены по 36 параметрам.

Выводы. В параметрах фонокардиограммы смежных по сроку гестации групп недоношенных детей существенных различий не выявлено. Выявлены существенные различия между средними показателями фонокардиограммы новорожденных 35-36 недель гестации и доношенными новорожденными 37- 41 недели гестации (всего по 36 параметрам).

Ключевые слова: электронная аускультация; параметры фонокардиограммы; новорожденные различного гестационного возраст.
29-31 and 32-34 weeks - in 10 parameters, 35-36 and 37-41 weeks were detected in 36 parameters.

Conclusions. There were no significant differences in the parameters of the phonocardiography of preterm infants of the contiguous gestational age groups. Significant differences were found between the average parameters of neonatal phonocardiograms 35-36 weeks of gestation and newborn infants 37-41 weeks of gestation (in total on 36 parameters).

Key words: Electronic Auscultation; Parameters of Phonocardiography; Newborns of Different Gestational Age.

\section{Контактна інформація:}

Шелевицька Вікторія Анатоліївна асистент кафедри педіатрії, сімейної медицини та клінічної лабораторної діагностики факультету післядипломної освіти Державного закладу «Дніпропетровська медична академія Міністерства охорони здоров'я України» (м. Дніпро, Україна)

Контактні дані: вул. С. Калачевського, 55, м.. Кривий Ріг, 50082, Україна.

Контактний телефон +38 (096) 5154062 e-mail: shelevika@gmail.com

ORCID: http://orcid.org/ 0000-0002-6941-6843

Researcher ID (Web of Science) H-8133-2018

() В.А. Шелевицька, 2018

\section{Контактная информация:}

Шелевицкая Виктория Анатольевна ассистент кафедры педиатрии, семейной медицины и клинической лабораторной диагностики фракультета последипломного образования Государственного учреждения «Днепропетровская медицинская академия Министерства здравоохранения Украины» (г. Днепро, Украина)

Контактные данные: ул. С Калачевского, 55, Кривий Рог, 50082, Украина. Контактный телефон: +38 (096) 5154062 e-mail: shelevika@gmail.com

ORCID: http://orcid.org/ 0000-0002-6941-6843 Researcher ID (Web of Science) H-81332018

(c) V. Shelevitska, 2018
Contact Information:

Shelevitska Victoria - MD, Assistant of Department of Pediatrics, Family Medicine and Clinical Laboratory Diagnostics of faculty of postgraduate education of the State institution «Dnipropetrovk medical academy of Ministry of health of Ukraine» (Dnipro, Ukraine).

Contact address: S. Kalachevsky st., 55, Kryvy Rih, 50082, Ukraine.

Contact phone +38 (096) 5154062 e-mail: shelevika@gmail.com ORCID: http://orcid.org/ 0000-0002-69416843

Researcher ID (Web of Science) $\mathrm{H}-8133-2018$

Надійшло до редакції 14.03.2018 Підписано до друку 15.06.2018 